\title{
Impact of corporate governance framework on the organizational performance
}

\author{
Nadia Ishaq Changezi, A. Saeed \\ FUIRC, Department of Business \& Economics. Foundation University, 44000, Islamabad, Pakistan \\ FUIRC, Department of Business \& Economics. Assistant Professor, FUIRC, Foundation University, 44000, \\ Islamabad, Pakistan
}

\begin{abstract}
This particular study has been conducted to find relationships between corporate governance and performance of banks in Pakistan. Corporate governance is the formal mechanism and the system by which management is held accountable to shareholders for its practices and policies. The theoretical stance of study reveals that effective corporate governance system result in high performance of organizations which also prohibits the fraudulent activities followed in the organizations. The independent variables of study include director's remuneration, communication strategies, code of conduct and governance mechanism. 10 branches of five major banks of Pakistan have been selected in this study. Response rate of $89 \%$ has been achieved in survey of 100 management respondents of selected banks. Through statistical analysis, it has been found that performance of banks also depends on the type of communication strategies, executive remuneration and Governance Mechanism. On the other hand, code of conduct does not influence on banks' performance. The regulatory authorities need to develop strong and effective corporate governance mechanisms and policies for the entire sector because corporate governance directly influences organizational performance.
\end{abstract}

\section{Introduction}

The social and economic lives are developed and governed by the specific institutions of governance. Corporate governance is regarded as the key foundation of organizations to be more productive, governed and controlled. In addition, the level of collapse of institutions and failure of firms across the world has also emphasized the researchers to study the ways by which organizations are governed and controlled. Lee (2008) defined corporate governance as follows: "Corporate governance is the system by which business corporations are directed and controlled. The corporate governance structure specifies the distribution of rights and responsibilities among different participants in the corporation, such as the board, managers, shareholders and other stakeholders, and spells out the rules and procedures for making decisions on corporate affairs. By doing this, it also provides the structure through which the company objectives are set, and the means of attaining those objectives and monitoring performance." It has been reported that the survival of firms is associated with the type of corporate governance and management followed in the organization. It is important to mention that large volume of the research regarding impact of corporate governance on the organizational performance has been conducted in perspective of western countries. In the perspective of Pakistan, rare evidence in this regard is obtained. To fill the literature gap, the proposed study is planned to evaluate the influence of corporate governance on the performance of banks in Pakistan.

Pakistan has been regarded as one of the important countries to be researched from the perspective of corporate governance practices. In Pakistan, the establishment of the Securities Exchange Commission of Pakistan paved the way for developing appropriate practices and "Code of Corporate Governance" for companies. Across the globe, there has been an increasing trend of exploring the dimensions of corporate governance and its impact on the performance of organizations. In the previous two decades, the concerns of organizations and regulatory authorizes have increased about the corporate governance practices. This is because previous two decades have been characterized for the collapse of major institutions such as Enron and WorldCom. The collapse of such bug institutions is attributed to poor and weak governance system. After the collapse of these big institutions have been influenced the regulatory authorities and government institutions to develop core and sound corporate governance practices. In this way, major changes have been brought into the corporate governance mechanism and relationships of management, board of directors and shareholders have been revised in the light of new practices of corporate governance across the globe. The authors and researchers have reported that in the current era, the interests of shareholders need to be protected and integrity of institutions and markets need to be maintained for ensuring smooth and far growth and development of economies (Bauer et al., 2004 and Dittmar \& Mahrt, 2007 and Abor \& Biekpe, 2007). All this cannot be attained unless organizations have a strong corporate governance system. These collapses and failures of these organizations have raised the questions regarding the effectiveness of corporate governance and its relationship with the corporate performance. Specifically from a perspective of Pakistan, rare literature is available regarding 
corporate governance system of organizations in Pakistan and its relationships with the corporate performance. In this regard, this particular study is appropriate and relevant to fill the literature gap.

The objectives of this study include:

- To study theoretical perspectives of corporate governance

- To determine relationships between corporate governance and performance of banks in Pakistan

- To propose ways by which sound Corporate Governance system can be achieved for banks in Pakistan.

\section{Literature review}

The term corporate governance has been defined as the mechanical process of setting rules, laws, regulations and accepted business practices of public and private organizations which govern the organizations between shareholders who invest money in the corporations, on one side and corporate managers who govern the investment and resources, on the other hand (Osisioma and Osisioma, 2005 and Thomsen, 2005). The investors may include financial institutions and creditors who supply debt finance to organizations whereas shareholders provide equity finance to organizations. On the other hand, employees provide human capital to organizations. In addition, investors also involve suppliers who provide intangible and tangible sources and assets which are crucial for the development and growth of organizations. The concept of corporate governance lies in between all these aspects and management of organizational resources fairly while concerning the interests of all stakeholders (Hermalin, 2005 and Lee, 2008). Contrary to these definitions, Bies (2004) has defined and explained corporate governance as the formal mechanism and the system by which management is held accountable to shareholders for its practices and policies. Contrary to this view, Westhead and Howorth (2006) suggest that corporate governance is the system which defines who are owners and who are the managers of the organization and also defines the regulations and rules for the allocation and management of organizational resources for attaining economic returns on resources and also defines the way of distribution of economic returns to shareholders, employees and managers. Dittmar \& Mahrt (2007) have categorized the line of difference between shareholders and managers and also discussed the responsibility of management for managing organizational resources to attain large scale benefits for society and corporate. In another perspective, Eroke (2007) has suggested that corporate governance is the system by which creditors and investors get assurance about adequate and reasonable rate of return on investment.

In this regard, it is arguable that the definitions of corporate governance have proposed different aspects of organizational performance, allocation of resources and ownership structures (Zheka 2007$)$. In this regard, the definitions of corporate governance have varied from a narrow scope of ownership structures to wider scope which defines the other dimensions of corporate governance such as size and composition of BoD, risk disclosure practices, executive compensation and rules and regulations of organizations. All these aspects have revealed that corporate governance not only assures about allocation of organizational resources but also elaborate what type of ownership structure is to be followed in the corporation. In broader or wider perspective, corporate governance points out the maximization of wealth of shareholders and fair economic growth (Cremers and Nair, 2005).

Authors have reported relationship between corporate governance and performance of organizations. For instance, Thomsen (2005) has noted that strong and effective corporate governance system result in high performance of organizations which also prohibits the fraudulent activities followed in the organizations. Furthermore, Black et al. (2006) evaluate that corporate governance systems and corporate performance are interrelated with each other. In the same vein, Qi et al (2000) have also evaluated that appropriate disclosure of information to stakeholders and strong corporate governance system result in better financial position of organizations. 


\section{Theoretical Framework of Study}

On the basis of literature review, following theoretical framework has been developed for this study:

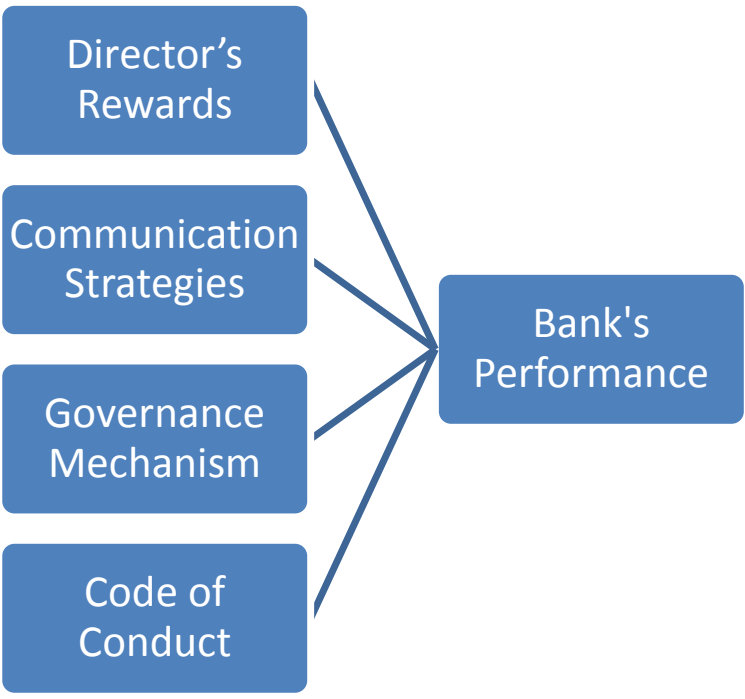

The hypotheses developed for this particular study are as follows:

H0: $\quad$ Director's rewards do not influence Banks' performance

H1: There exists a relationship between Director's rewards and Banks' performance

H0: $\quad$ Communication strategies have no influence on banks' performance

H1: $\quad$ Communication strategies influence banks' performance

H0: $\quad$ Governance mechanisms have no influence on banks' performance

H1: $\quad$ Governance mechanisms influence banks' performance

H0: $\quad$ Code of conduct of banks has no influence on banks' performance

H1: $\quad$ Code of conduct of banks influence banks' performance

\subsection{Methodology}

This particular study has been based on the case study research design of Pakistani banks. By taking a group of 5 banks of Pakistan, the relationship between corporate governance and bank's performance has been elaborated and discussed. The case study research design has been used in this study because it is suitable to get empirical evidence of relationships between corporate governance and bank's performance. In this regard, the case study research design has suggested using quantitative research methods for exploring the impact of relationships between the two variables of the study.

This particular study has been based on pragmatic methods which include implementation of qualitative and quantitative research methods and data collection approaches. Through a qualitative research method, previous research and theoretical basis of corporate governance has been conducted. On the other hand, quantitative methods have associated with attaining empirical evidence of relationships between corporate governance and bank's performance. Through a triangulation approach, the author has obtained explanatory as well as empirical evidence of the impact of corporate governance on banks' performance. The data collection tools and data analysis approach implemented in the current study is aligned with pragmatic research approach.

This particular study involved collection of data from management respondents of the selected banks in Pakistan. This data was primary in nature. For collection of primary data, close end questionnaire survey has been conducted. This questionnaire involved all variables of study i.e. Director's rewards, communication strategies, code of conduct and, banks' performance and corporate governance mechanism. For each variable, sub questions have been developed. All these questions have been directed to evaluate the extent to which each of them impacts the performance of banks.

For conducting this study, 10 Pakistani banks have been selected from Islamabad region. In this way, the population of this particular study is composed of management respondents of these selected banks. These banks have been selected on a random selection basis. From these selected banks, sample of 100 management respondents has been selected through convenience sampling technique. Response rate of $89 \%$ has been achieved in this study.

The data collected through close end questionnaire survey has been statically analysed in this study. In this regard, regression analysis has been performed to evaluate the relationships between corporate governance and 
performance of banks. The data has been tabulated and further put to statistical analysis. The results of statistical analysis have been interpreted to approve or discard the hypotheses of the study.

\section{Empirical findings}

The statistical analysis of this particular study has evaluated that corporate governance impacts the performance of banks in several respects. The statistical results of survey have revealed that the participants agreed that banks have an effective and strong system of corporate governance. In this regard, $61 \%$ respondents have agreed that corporate governance in their banks is strong and responsive. In the same vein, $63 \%$ respondents of the study have agreed that the performance of the organization has gradually improved over the last three years because of improvements brought in the corporate governance mechanisms of the banks. This shows that the management of selected banks also agreed that corporate governance impacts the performance of banks. The results of this study have also reflected that return on assets of the selected banks has also improved in the last three years. Irrespective of varying forms of ownership structures followed in the selected banks, the results of survey have revealed that the banks' performance has improved over the period of three years. In this way, the results of this study reflected that ownership structure and mechanism are independent of organizational performance.

For evaluating the impact of corporate governance mechanism on the performance of banks, statistical analysis has been conducted in this study. In this regard, ANOVA test has been applied to develop regression analysis. The ANOVA test results have clearly elaborated the extent to which corporate governance mechanism of banks impacts banks' performance. The model summary of statistical analysis of this study is as follows:

Model Summary

\begin{tabular}{|c|c|c|c|c|c|}
\hline Model & & $\mathrm{R}$ & R Square & Square & $\begin{array}{l}\text { Std. Error of } \\
\text { the Estimate }\end{array}$ \\
\hline dimension0 & 1 & $.974^{\mathrm{a}}$ & .948 & .946 & .51740 \\
\hline
\end{tabular}

a. Predictors: (Constant), Corporate Governance Mechanism, Code of Conduct, Director's Rewards and Communication Strategies

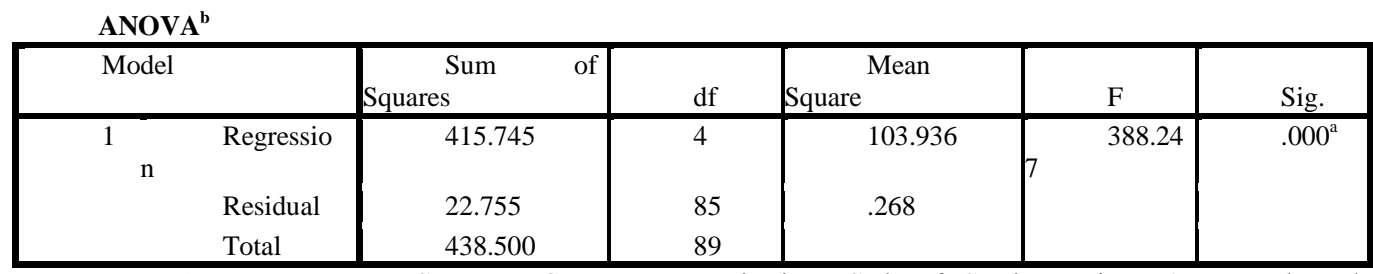

a. Predictors: (Constant), Corporate Governance Mechanism, Code of Conduct, Director's Rewards and Communication Strategies

b. Dependent Variable: Banks’ Performance

The statistical results of this particular study have clearly elaborated that corporate governance and organizational performance have significant relational with each other. In addition, the statistical results of this study also clearly suggest that corporate governance has significant impact on the bank's performance in either direction. In this regard, the value of $\mathrm{R}$ in the above table is noticeable. This value is highly close to 1 which suggests that overall model of the study is significant and also confirms that corporate governance mechanisms of selected banks impact the performance of the banks.

The results of the coefficients of this study have been given in the following table: Coefficients

\begin{tabular}{|c|c|c|c|c|c|}
\hline \multirow[t]{2}{*}{ Model } & \multicolumn{2}{|c|}{ Unstandardized Coefficients } & \multirow{2}{*}{\begin{tabular}{|r|}
$\begin{array}{l}\text { Standardized } \\
\text { Coefficients }\end{array}$ \\
Beta \\
\end{tabular}} & \multirow[b]{2}{*}{$\mathrm{t}$} & \multirow[b]{2}{*}{ Sig. } \\
\hline & $\mathrm{B}$ & Std. Error & & & \\
\hline (Constant) & .197 & .182 & & 1.084 & .281 \\
\hline Director's Rewards & .290 & .052 & .285 & 5.528 & .000 \\
\hline Governance Mechanism & .566 & .058 & 1.037 & 9.820 & .000 \\
\hline Communication Strategies & .114 & .015 & .241 & 7.792 & .000 \\
\hline Code of Conduct & .112 & .074 & .128 & 1.504 & .136 \\
\hline
\end{tabular}

a. Dependent Variable: Banks' Performance

On the basis of above table, it has been evaluated that the corporate governance has a significant relationship with the performance of banks. The statically analysis has revealed that the level of significance of 
a variety of study is less than 0.05 . In this regard, the level of significant is less than 0.05 for director's rewards, governance mechanism, and mode of communication. This shows that all these variables have been significantly related with the performance of banks. Contrary to this, the results of this study have also depicted that code of conduct of banks is not significant towards bank's performance. This shows that the code of conduct followed in the bank does to define the performance of banks.

The results of this particular study are aligned with the results of previous studies conducted by (Cremers and Nair, 2005; Westhead and Howorth, 2006 and Dittmar \& Mahrt, 2007) which suggest that the corporate governance practices of organizations influence the organizational performance.

On the basis of the results of this study, the following results have been derived regarding hypotheses: It has been proved that there exists a relationship between Director's rewards and Banks' performance. It has been found that communication strategies influence banks' performance. Governance mechanisms influence banks' performance and code of conduct of banks has no influence on banks' performance.

\section{Conclusion}

This particular study has been conducted to evaluate the relationship between corporate governance mechanism and banks' performance in the major banks of Pakistan. In order to evaluate the aims and objectives of this study, four important variables have been identified. These variables included communication strategies, executive's rewards, and code of conduct and governance mechanisms. On the basis of statistical analysis of study, it has been concluded that the performance of the bank has a significant association with the corporate governance system of the banks. The descriptive results of this study have shown that the director's remuneration or rewards also depend on the performance of the banks. Hence, the directors are more likely to adopt those practices which result in higher performance of the banks. However, in broader perspective, it is noteworthy that such actions of directors and executives may lead to unstable performance of the organizations in the long run. The descriptive results have also noticed that $60 \%$ survey respondents suggested that they had no conflicts or disagreements with the senior management and directors of the banks. In the same vein, the statistical results have also supported this stance. Likewise, Li et al (2010) has also suggested that remuneration of directors influences bank' performance. In addition, it has also been concluded that the performance of banks also depends on the type of communication strategies followed in the banks. The banks arrange routine tasks and frequent meetings on timely schedules and also ensure effective communication practices. In this respect, the results of Hermalin (2005) have also suggested that strong communication strategy of an organization influence the performance outcomes. Finally, it has been concluded that the code of conduct adopted in the banks has no relations and association with the performance outcomes.

The results of this particular study have certain managerial implications for improving corporate governance mechanism and ensuring higher performance of the organization. The first practical managerial implication of this study is to have a strong corporate governance mechanism. The managers of organizations need to understand that there exist an association between corporate governance and organizational performance. When managers understand about this important association, they are more likely to govern companies effectively.

The second implementation of this study is for the regulatory authorities to develop strong and effective corporate governance mechanisms and policies for the entire sector because corporate governance directly influences organizational performance. Finally, there is need to have a strong and effective communication between management and shareholders of the organizations. This is because when both communicate with each other; they remain aware of the corporate governance practices followed in the organization and are more likely to positively influence the organizational performance.

This particular study has been conducted through mixed methods and survey technique. However, this study has been conducted with a relatively small sample. In this regard, future researchers have the opportunity to extend the scope of this particular study. In this regard, the use of large and diverse sample will be effective for expanding the scope of this study. In addition, use of qualitative research tools such as interviews will be effective to get more explanation regarding the corporate governance practices of the banks.

\section{Reference}

[1]. Abor, J., \& Biekpe, N. (2007). Corporate governance, ownership structure and performance of SMEs in Ghana: implications for financing opportunities, Journal of Corporate Governance, Vol. 7, No. 3, pp. 288-300.

[2]. Bauer, R., Guenster, N., Otten, Roger, (2004). Empirical evidence on corporate governance in Europe: the effect on stock returns, firm value and performance. Journal of Asset Management. Vol. 5, pp. 91-104.

[3]. Black, B., Jang, H., Kim, W., (2006). Does corporate governance predict firms' market values? Evidence from Korea. Journal of Law, Economics, and Organization. Vol. 22, pp. 366-413.

[4]. Bies, V (2004). Corporate Governance and Corporate Culture, the Intercourse, International Journal of Management, 66(2) 103.

[5]. Cremers, M.K.J and Nair, V.B., (2005). Governance mechanisms and equity prices. Journal of Finance. Vol. 60, pp. $2859-2894$

[6]. Dittmar, A., \& Mahrt-Smith, J. (2007). Corporate governance and the value of cash holdings. Journal of Financial Economics, Vol. 83(3), pp. 599-634. 
[7]. Eroke M.O. (2007) Elements of Business Management, The Nigerian Experience, Enugu: Academic Publishers

[8]. Hermalin, B. (2005). Trends in corporate governance. The Journal of Finance, Vol. 60, pp. 2351-2384.

[9]. Lee T. A. (2008). Financial Reporting \& Corporate Governance. John Wiley \& Sons. West Sussex.

[10]. Li, L., Naughton, T., \& Hovey, M. (2010). A review of corporate governance in China. Working Paper, RMIT University.

[11]. Osisioma, B.C. and Osisioma, H.E (2002) Management Practice, Manual for the Professional Management Student (2nd Ed) Enugu: SNAAPS

[12]. Qi, D, Wu, W., \& Zhang, H. (2000). Shareholding structure and corporate performance of partially privatized firms: Evidence from listed Chinese companies. Pacific-Basin Finance Journal, Vol. 8, pp. 587-610.

[13]. Thomsen S., (2005). Corporate governance as a determinant of corporate values. Emerald Group Publishing Limited. Vol. 5. pp. 1027

[14]. Westhead, P and Howorth, C (2006), Ownership and Management Issues Associated With Family Firm Performance and Company Objectives, Family Business Review, Vol. 19(4), pp. 301-316.

[15]. Zheka, V, (2007). Does Corporate Governance Predict Firms 'e Performance? The Case of Ukraine. Empirical Legal Studies Paper. Vol. 5

\section{Dear Respondents,}

\section{Appendix}

I have been conducting a research to explore the relationship between corporate governance and banks' performance. You are requested to fill the following questionnaire as per policies and practices of your respective banks.

\section{Regards}

At present, how many directors are there in the board of directors how controlling authority has?

- $1-3$

- $4-6$

- $7-9$

- $10-13$

- More than 13

On the basis of scale, please fill the following questionnaire. (Strongly agree $=1$, Neutral $=3$ and strongly disagree $=5$, Agree $=2$ and Disagree $=4$ )

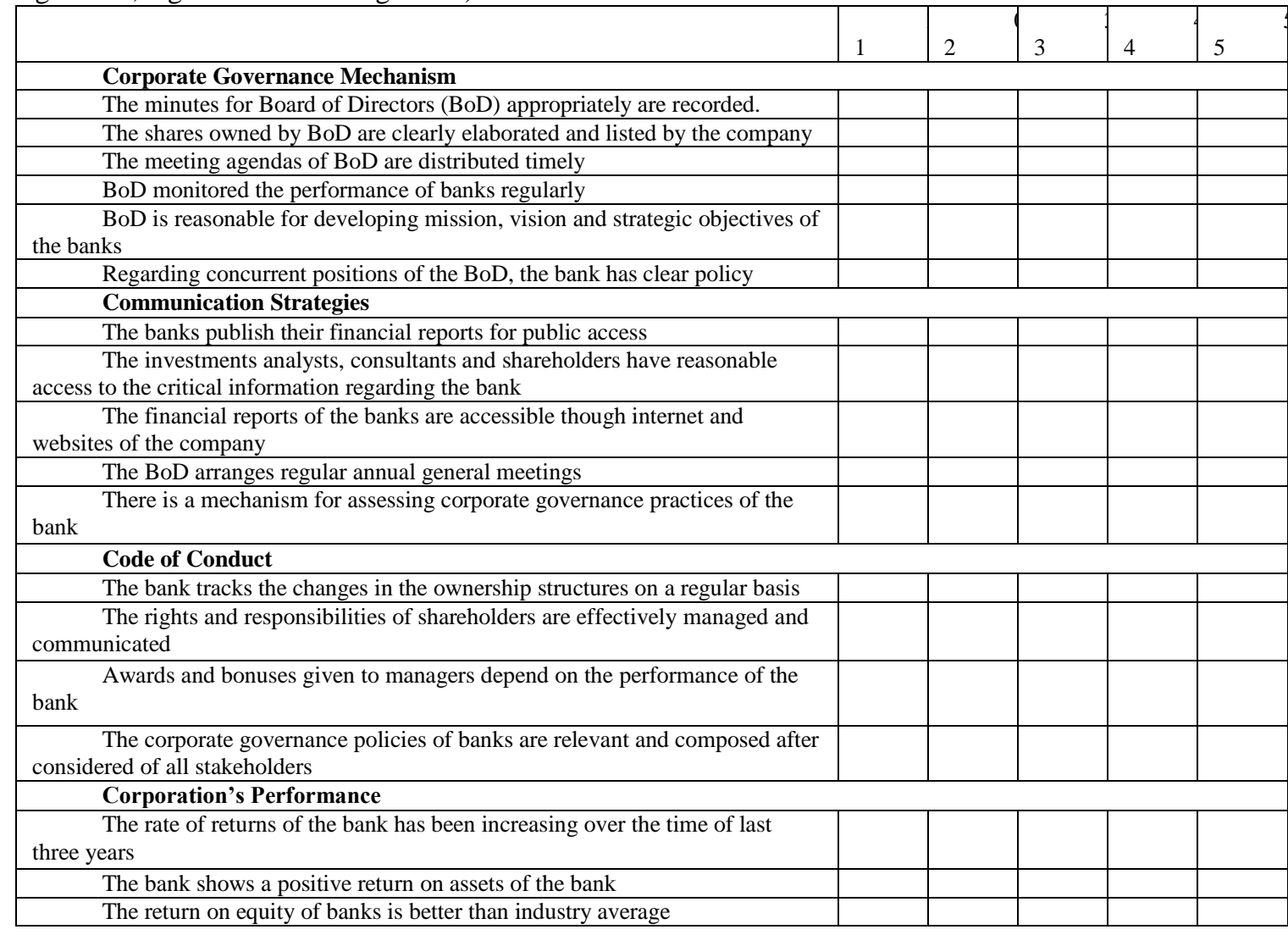

